\title{
Asas Tanggung Jawab Negara Sebagai Dasar Pelaksanaan Perlindungan dan Pengelolaan Lingkungan Hidup
}

\author{
Sudi Fahmi \\ Fakultas Hukum Universitas Lancang Kuning \\ Jalan Yos Sudarso Km. 8 Pekanbaru \\ sudi.fahmi@ymail.com
}

\begin{abstract}
Based on the principle of state responsibility, the state will guarantee that the utilization of natural resources will provide benefits for the greater well-being and quality of life, both present and future generations as a goal of the implementation of sustainable development. The problems that would be investigated are; first, how is the state responsibility as a basis of the implementation of environmental protection and management? Second, how is the implementation of state responsibility as a basis of the implementation of environmental protection and management? The method used in this research is juridical normative with regulation approach. The analyze method used is qualitative analysis. The research concludes that the principle of state responsibility position as the basis for the implementation of environmental protection and management means: 1) State guarantees that the utilization of natural resources would provide benefits for the greater well-being and quality of life, both present and future generations. 2) State guarantees the rights of citizen for a good and healthy living environment. 3) State prevents the use of natural resources activities that cause pollution and/ or damage the environment.
\end{abstract}

Key words : State responsibility, environmental protection and management.

\begin{abstract}
Abstrak
Berdasarkan asas tanggung jawab negara, negara akan menjamin pemanfaatan sumber daya alam akan memberikan manfaat yang sebesar-besarnya bagi kesejahteraan dan mutu hidup rakyat, baik generasi masa kini maupun generasi masa depan sebagai tujuan dilaksanakannya pembangunan yang berkelanjutan. Masalah yang akan diteliti: Pertama, bagaimana tanggung jawab negara sebagai dasar pelaksanaan perlindungan dan pengelolaan lingkungan hidup? Kedua, bagaimana pelaksanaan tanggung jawab negara sebagai dasar pelaksanaan perlindungan dan pengelolaan lingkungan hidup? Metode yang digunakan dalam penelitian ini adalah yuridis normatif dengan disertai dengan pendekatan perundang-undangan. Metode dianalisis yang digunakan adalah analisis kualitatif. Hasil penelitian menyimpulkan, bahwa kedudukan asas tanggung jawab negara sebagai dasar pelaksanaan perlindungan dan pengelolaan lingkungan hidup mengandung arti: 1) Negara menjamin pemanfaatan sumber daya alam yang akan memberikan manfaat yang sebesar-besarnya bagi kesejahteraan dan mutu hidup rakyat, baik generasi masa kini maupun generasi masa depan. 2) Negara menjamin hak warga negara atas lingkungan hidup yang baik dan sehat. 3) Negara mencegah dilakukannya kegiatan pemanfaatan sumber daya alam yang menimbulkan pencemaran dan/atau kerusakan lingkungan hidup.
\end{abstract}

Kata kunci : Tanggung jawab negara, perlindungan dan pengelolaan lingkungan hidup. 


\section{Pendahuluan}

Pengaturan permasalahan lingkungan hidup di Indonesia mengalami beberapa lompatan besar sejak diundangkannya Undang-Undang Nomor 4 Tahun 1982 tentang Ketentuan-ketentuan Pokok Pengelolaan Lingkungan Hidup, kemudian digantikan dengan Undang-Undang Nomor 23 Tahun 1997 tentang Pengelolaan Lingkungan Hidup, dan terakhir digantikan dengan diberlakukannya Undang-Undang Nomor 32 Tahun 2009 tentang Perlindungan dan Pengelolaan Lingkungan Hidup.

Salah satu yang menjadi perhatian dalam ketiga undang-undang ini adalah makin kuatnya peran negara dalam rangka menyediakan lingkungan hidup yang baik dan sehat sebagai sarana rakyat Indonesia berkehidupan. Undang-Undang Dasar Negara Republik Indonesia Tahun 1945 telah menyatakan bahwa lingkungan hidup yang baik dan sehat merupakan hak asasi dan hak konstitusional bagi setiap warga negara Indonesia.

Karena itu, negara, pemerintah, dan seluruh pemangku kepentingan berkewajiban untuk melakukan perlindungan dan pengelolaan lingkungan hidup dalam pelaksanaan pembangunan berkelanjutan agar lingkungan hidup Indonesia dapat tetap menjadi sumber dan penunjang hidup bagi rakyat Indonesia serta makhluk hidup lain.

Peran negara dirasakan penting karena sebagai negara yang terus berkembang, di Indonesia telah terjadi beberapa kasus penting terkait permasalahan lingkungan hidup antara lain kasus banjir lumpur yang terjadi di Sidoarjo, yang walaupun sudah terjadi selama beberapa tahun, namun hingga kini belum tuntas penanganannnya. Terlepas adanya perdebatan apakah tragedi semburan lumpur tersebut terjadi akibat adanya bencana alam atau ulah manusia, negara tetap harus melaksanakan tanggung jawabnya untuk mengelola dan melindungi kondisi lingkungan yang menjadi lokasi banjir lumpur.

Pada pelaksanaan perlindungan dan pengelolaan lingkungan hidup, negara bekerja dengan berlandaskan pada beberapa asas, salah satunya adalah asas tanggung jawab negara, yang menjadikan negara sebagai titik sentral dan acuan. Negara mempunyai peran penting dan sentral. 


\section{Rumusan masalah}

Pertama, bagaimana tanggung jawab negara sebagai dasar pelaksanaan perlindungan dan pengelolaan lingkungan hidup? Kedua, bagaimana pelaksanaan tanggung jawab negara sebagai dasar pelaksanaan perlindungan dan pengelolaan lingkungan hidup?

\section{Tujuan penelitian}

Pertama, untuk mengetahui tanggung jawab negara sebagai dasar pelaksanaan perlindungan dan pengelolaan lingkungan hidup? Kedua, untuk mengetahui pelaksanaan tanggung jawab negara sebagai dasar pelaksanaan perlindungan dan pengelolaan lingkungan hidup?

\section{Metode penelitian}

Metode pendekatan yang digunakan dalam penelitian ini adalah yuridis normatif dengan disertai dengan pendekatan perundang-undangan. Dalam metode pendekatan perundang-undangan perlu memahami hierarki, dan asas-asas dalam peraturan perundang-undangan. ${ }^{1}$ Metode yuridis normatif menitikberatkan kepada aspek filosofis pembentukan dasar pengaturan tanggung jawab social perusahaan. Metode ini akan mengkaji aturan mengenai tanggung jawab negara dalam perlindungan dan pengelolaan lingkungan hidup.

Metode yuridis normatif yang akan digunakan menggunakan bahan hukum primer, sekunder, dan tersier. Dalam penelitian ini akan digunakan bahan hukum primer seperti Undang-Undang Dasar 1945, Undang-Undang Nomor 32 Tahun 2009 tentang Perlindungan dan Pengelolaan Lingkungan Hidup. Bahan sekunder diperoleh dari bahan-bahan kepustakaan, seperti artikel, produk dari forum-forum ilmiah dan hasil karya tulis lainnya. Bahan hukum tersier yang memberikan petunjuk maupun penjelasan terhadap bahan hukum primer. Hasil penelitian ini nantinya akan dianalisis secara kualitatif dengan pendekatan yuridis normatif dengan pendekatan perundang-undangan. Metode yang demikian ini tidak menitikberatkan kepada aspek kuantitas data yang diperoleh semata melainkan

${ }^{1}$ Peter Mahmud Marzuki, Penelitian Hukum, Kencana Prenada Media Group, Jakarta, 2006, hlm. 96. 
juga mementingkan kedalaman analisis hukumnya. Metode analisis kualitatif ini dilakukan untuk mengetahui bagaimana kedudukan asas tanggung jawab negara sebagai dasar pelaksanaan perlindungan dan pengelolaan lingkungan hidup dan bagaimana pelaksanaan asas tanggung jawab negara sebagai dasar pelaksanaan perlindungan dan pengelolaan lingkungan hidup.

\section{Hasil Penelitian dan Pembahasan}

\section{Kedudukan Asas Tanggung Jawab Negara sebagai Dasar Pelaksanaan Perlindungan dan Pengelolaan Lingkungan Hidup}

Pembahasan asas tanggung jawab negara sebagai dasar pelaksanaan perlindungan dan pengelolaan lingkungan hidup akan bersinggungan dengan beberapa istilah yang harus dijelaskan terlebih dahulu, beberapa istilah tersebut adalah: Pertama, lingkungan hidup, yaitu kesatuan ruang dengan semua benda, daya, keadaan, dan makhluk hidup, termasuk manusia dan perilakunya, yang mempengaruhi alam itu sendiri, kelangsungan perikehidupan, dan kesejahteraan manusia serta makhluk hidup lain. Kedua, pembangunan berkelanjutan yaitu upaya sadar dan terencana yang memadukan aspek lingkungan hidup, sosial, dan ekonomi ke dalam strategi pembangunan untuk menjamin keutuhan lingkungan hidup serta keselamatan, kemampuan, kesejahteraan, dan mutu hidup generasi masa kini dan generasi masa depan. Ketiga, pengelolaan dan perlindungan lingkungan hidup yaitu upaya sistematis dan terpadu yang dilakukan untuk melestarikan fungsi lingkungan hidup dan mencegah terjadinya pencemaran dan/atau kerusakan lingkungan hidup yang meliputi perencanaan, pemanfaatan, pengendalian, pemeliharaan, pengawasan, dan penegakan hukum. Keempat, pemerintah pusat, yang selanjutnya disebut Pemerintah, adalah Presiden Republik Indonesia yang memegang kekuasaan pemerintahan Negara Republik Indonesia sebagaimana dimaksud dalam Undang-Undang Dasar Negara Republik Indonesia Tahun 1945. Kelima, pemerintah daerah adalah gubernur, bupati, atau walikota, dan perangkat daerah sebagai unsur penyelenggara pemerintah daerah.

Asas, tujuan dan ruang lingkup perlindungan dan pengelolaan lingkungan hidup diatur dalam Pasal 2, Pasal 3 dan Pasal 4 Undang-Undang Nomor 32 Tahun 2009 tentang Perlindungan dan Pengelolaan Lingkungan Hidup. Asas yang menjadi dasar pelaksanaan perlindungan dan pengelolaan lingkungan hidup adalah: a. 
tanggung jawab negara; b. kelestarian dan keberlanjutan; c. keserasian dan keseimbangan; d. keterpaduan; e. manfaat; f. kehati-hatian; g. keadilan; h. ekoregion; i. keanekaragaman hayati; j. pencemar membayar; k. partisipatif; 1. kearifan lokal; m. tata kelola pemerintahan yang baik; dan $n$. otonomi daerah.

Pelaksanaan perlindungan dan pengelolaan lingkungan hidup yang dilaksanakan bertujuan untuk: 1. melindungi wilayah Negara Kesatuan Republik Indonesia dari pencemaran dan/atau kerusakan lingkungan hidup; 2. menjamin keselamatan, kesehatan, dan kehidupan manusia; 3. menjamin kelangsungan kehidupan makhluk hidup dan kelestarian ekosistem; 4. menjaga kelestarian fungsi lingkungan hidup; 5. mencapai keserasian, keselarasan, dan keseimbangan lingkungan hidup; 6. menjamin terpenuhinya keadilan generasi masa kini dan generasi masa depan; 7. menjamin pemenuhan dan perlindungan hak atas lingkungan hidup sebagai bagian dari hak asasi manusia; 8 . mengendalikan pemanfaatan sumber daya alam secara bijaksana; 9. mewujudkan pembangunan berkelanjutan; dan 10. mengantisipasi isu lingkungan global.

Ruang lingkup pelaksanaan perlindungan dan pengelolaan lingkungan hidup meliputi: a. perencanaan; b. pemanfaatan; c. pengendalian; d. pemeliharaan; e. pengawasan; dan f. penegakan hukum. Tujuan perlindungan dan pengelolaan lingkungan hidup akan tercapai apabila pemerintah baik pemerintah pusat, pemerintah daerah dan segenap warga negara dengan koordinasi negara dalam pelaksanaan asas tanggung jawab negara.

Hal ini sejalan dengan tujuan negara Indonesia, sebagaimana tercantum dalam alenia keempat pembukaan UUD 1945, adalah: “... Melindungi segenap bangsa Indonesia dan seluruh tumpah darah Indonesia dan untuk memajukan kesejahteraan umum, mencerdaskan kehidupan bangsa dan ikut melaksanakan keteriban dunia yang berdasarkan kemerdekaan, perdamaian abadi dan keadilan sosial..."

Pokok persoalan lingkungan hidup di negara maju dan negara berkembang adalah terletak pada ketidak seimbangan dalam lingkungan hidup yang merupakan hal pokok bagi prikehidupan manusia. ${ }^{2}$

Lingkungan sebagai sumber daya merupakan aset yang diperlukan untuk menyejahterakan masyarakat. Hal ini sesuai dengan perintah Pasal 33 ayat (3) Undang-Undang Dasar 1945 yang menyatakan bahwa: “ bumi, air dan kekayaan

${ }^{2}$ Moh Soerjani, Lingkungan: Sumber Daya Alam dan Kependudukan dalam Pembangunan, Penerbit Universitas Indonesia, Jakarta, 1987, hlm. 187. 
alam yang terkandung didalamnya dipergunakan untuk sebesar-besarnya kemakmuran rakyat dalam rangka pelaksanaan kekuasaan negara".

Kekuasaan negara berkaitan dengan tanggung jawab dan kewajiban. Dilihat dari segi perkembangan negara demokrasi, dua hal ini merupakan unsur dari kesatuan pengertian kekuasaan. Dewasa ini hampir tidak ada suatu kekuasaan yang tidak diikuti oleh tanggung jawab dan kewajiban. Sebab bila tidak, hal demikian mengarah kepada negara totaliter. Dengan demikian kekuasaan akan diikuti kemudian, baik dengan kewajiban maupun tanggung jawab, karena keduanya memiliki hubungan konsekuensi. Dalam demokrasi, kemampuan manajemen pemerintahan biasanya diukur oleh dua hal: kemampuan mengelola dukungan politik bagi pemerintahan dan kemampuan mengelola kebijakan hingga dirasakan oleh orang banyak. ${ }^{3}$

Dalam sistem pemerintahan modern, kekuasaan yang tidak diikuti oleh tanggung jawab penguasanya sudah ditinggalkan berhubung aspek pengendalian yang datang dari pihak masyarakat sudah demikian besar. Demikian juga tidak kecualinya kepada aspek pengelolaan sumber daya alam dan lingkungan. Negara tidak hanya berperan menguasai dan mendapatkan manfaat yang sebesar-besarnya, meskipun hal itu kemudian ditujukan untuk sebesar-besarnya kemakmuran rakyat. ${ }^{4}$

Dalam sistem pengelolaan lingkungan dikenal negara memiliki kekuasaan atas semua sumber daya alam. Negara melalui pemerintah pusat dan pemerintah daerah berwenang untuk mengatur, mengendalikan dan mengembangkan segala hal yang berkenaan dengan perlindungan dan pengelolaan lingkungan guna menjamin pemanfaatan sumber daya alam akan memberikan manfaat yang sebesar-besarnya bagi kesejahteraan dan mutu hidup rakyat, baik generasi masa kini maupun generasi masa depan.

Negara memiliki tanggung jawab dalam pengelolaan lingkungan untuk mewujudkan pembangunan berkelanjutan. Asas tanggung jawab negara (state responsibility) demikian, sebagaimana ditentukan pada Pasal 2 huruf a memiliki pengertian yang cukup luas, termasuk pula dengan mengkaitkan paradigma yang melibatkan peran serta masyarakat (community based management) tersebut. Karena itu, tanggung jawab negara dapat dikaitkan dengan tugas-tugas dan fungsi semua aparat dalam menjalankan pemerintahan yang baik (good governance).

\footnotetext{
${ }^{3}$ Eep Saefulloh Fatah, "Betapa Lemahnya Pemerintah”, Kompas, 6 September 2006.

${ }^{4}$ N.H.T. Siahaan, Hukum Lingkungan, Pancuran Alam, Jakarta, 2009, hlm. 123.
} 
Prinsip good governance, merupakan paradigma baru di sektor kehidupan, mulai dari politik, ekonomi, hukum dan sosial. Bilamana selama ini dianut paradigma klasik bahwa pemerintahlah yang mengatur, menjalankan, menentukan dan memutuskan dengan apa yang disebut government is to govern, akan tetapi sekarang telah bergeser kepada paradigma baru, yakni pemerintahlah yang melayani rakyatnya (government is to serve the people). Paradigma ini menimbulkan konsekuensi lebih jauh dimana pemerintah dari peran penguasa menjadi peran pelayan masyarakat di suatu negara. ${ }^{5}$

Good governance hanya bisa dicapai apabila pemerintah dalam melaksanakan tugasnya berpedoman kepada konsep rule of law, yang mempunyai lima karakteristik sebagai berikut: ${ }^{6}$ 1. pemerintah melaksanakan kewenangannya berdasarkan supremasi hukum; 2. pemerintah menjamin kepastian hukum; 3. pemerintah harus menciptakan hukum yang responsif yang mampu menyerap aspirasi masyarakat; 4. pemerintah harus melaksanakan hukum secara konsisten dan non diskriminatif melalui penciptaan mekanisme menjalankan sanksi; 5. pemerintah harus menciptakan dan menjamin terlaksananya independen peradilan.

\section{Pelaksanaan Asas Tanggung Jawab Negara sebagai Dasar Pelaksanaan Perlindungan dan Pengelolaan Lingkungan Hidup.}

Kekuasaan negara yang luas terhadap bumi, air, udara dan segala yang terkandung didalamnya sesuai dengan asas konstitusional, tentu pula merefleksikan adanya tanggung jawab yang sangat besar pula. ${ }^{7}$ Kekuasaan negara harus pula diikuti dengan pengaturan perlindungan dan pengelolaan lingkungan berisi kepentingan rakyat banyak, pemeliharaan alam dan lingkungan, pencegahan pencemaran, perlindungan terhadap segala ancaman yag merusak dan berpotensi merugikan alam dan lingkungan, serta bertanggung jawab atas hal-hal yang merugikan masyarakat dari kerusakan alam dan lingkungan termasuk bencana alam.

Mac Iver mengemukakan tiga tugas pemerintah dengan menggolongkannya menjadi : (1) cultural function; (2) general welfare function; (3) economic control function. ${ }^{8}$

\footnotetext{
${ }^{5}$ Safri Nugraha, "Hukum Administrasi dan Good Governance", Piadato pada Upacara Pengukuhan Guru Besar Tetap pada Universitas Indonesia, 13 September 2006, hlm. 4.

${ }^{6}$ Mas Achmad Santosa, Good Governance \& Hukum Lingkungan, Indonesian Centre For Environmental Law, Jakarta, 2001, hlm. 87.

${ }^{7}$ Ibid., hlm. 123

${ }^{8}$ Ateng Syarifudin, Memantapkan Pemerintahan Yang Bersih Kuat dan Berwibawa, Tarsito, Bandung, 1982, hlm. 15.
} 
Tugas pemerintah bergantung kepada tugas dan tujuan masing-masing negara. Perkembangan negara di dunia memperlihatkan gerak menuju bentuk negara kesejahteraan (welfare state).

Empat unsur dan karakteristik dari negara hukum kesejahteraan, yaitu: ${ }^{9} 1$. hukum dasar memberikan perlindungan sosial secara khusus yang menjadi sumber hukum dari semua hukum dari semua peraturan perundang-undangan dalam urusan sosial; 2 . hewajibkan pemerintah untuk mengadakan segala kebutuhan rakyat dalam berbagai hak yang benar-benar nyata sesuai dengan cita-cita dalam undangundang dasar; 3. undang-undang harus memacu atau membangkitkan pengadaan jaminan sosial yang baru untuk mendorong hak-hak rakyat; 4. ualam berbagai hak yang tidak bertentangan dengan undang-undang dasar terlebih dahulu harus dikonsultasikan dengan parlemen.

Friedmann mengemukakan empat fungsi negara, yaitu: ${ }^{10} 1$. sebagai provider, negara bertanggung jawab dan menjamin suatu standar minimum kehidupan secara keseluruhan dan memberikan jaminan sosial lainnya; 2. sebagai regulator, negara mengadakan aturan kehidupan bernegara; 3. sebagai entrepreneur, negara menjalankan sektor ekonomi melalui badan usaha milik negara/ daerah dan menciptakan suasana yang kondusif untuk berkembangnya bidang-bidang usaha; 4. sebagai umpire, negara menetapkan standar-standar yang adil bagi pihak yang bergerak di sektor ekonomi, terutama antara sektor negara dan sektor swasta atau antar bidang-bidang usaha-usaha tertentu.

Tujuan negara Indonesia, sebagaimana tercantum dalam alenia keempat pembukaan UUD 1945, adalah: “...Melindungi segenap bangsa Indonesia dan seluruh tumpah darah Indonesia dan untuk memajukan kesejahteraan umum, mencerdaskan kehidupan bangsa dan ikut melaksanakan keteriban dunia yang berdasarkan kemerdekaan, perdamaian abadi dan keadilan sosial..." Dengan demikian dapat disimpulkan tugas pokok negara Indonesia sebagai negara hukum kesejahteraan adalah tidak jauh berbeda dengan negara kesejahteraan pada umumnya. Untuk mencapai tujuan negara sebagai organisasi kekuasaan, pemerintah menempati kedudukan yang istimewa. Hal ini di sebabkan pemerintah diatur oleh hukum khusus yaitu hukum administrasi sebagai instrumen pemerintah untuk

${ }^{9}$ Lukmanul Hakim, Kedudukan Hukum Komisi Negara di Indonesia; Eksistensi Komisi-komisi Negara (State Auxiliary Agency) Sebagai Organ Negara yang Mandiri Dalam Sistem Ketatanegaraan, Program Pasca Sarjana Universitas Brawijaya Malang, Puskasi Universitas Widyagama malang dan Setara Press (Kelompok Penerbit Intrans), Malang, 2010, hlm. 48.

${ }^{10}$ Ibid., hlm. 49-50. 
secara aktif turut campur dalam kehidupan bersama masyarakat sekaligus hukum yang memberikan perlindungan kepada anggota kehidupan bersama itu.

Bila mendasarkan aspek kekuasaan yang berlandaskan dan berumber dari instrumen hukum yang kuat dan jelas yakni UUD 1945 dan UU Nomor 32 Tahun 2009 tentang Perlindungan dan Pengelolaan Lingkungan Hidup, maka pada dasarnya negara pun sebenarnya harus bertanggung jawab pula secara yuridis atas semua hal yang menjadi objek penguasaannya. ${ }^{11}$

Lingkungan hidup adalah salah satu bidang yang harus diperhatikan oleh negara, karena adanya asas tanggung jawab negara di dalam proses perlindungan dan pengelolaannya. Berdasarkan asas tanggung jawab negara, negara akan melakukan beberapa hal di bidang perlindungan dan pengelolaan lingkungan hidup, yaitu:

Negara Menjamin Pemanfaatan Sumber Daya Alam akan Memberikan Manfaat yang Sebesar-besarnya bagi Kesejahteraan dan Mutu Hidup Rakyat, Baik Generasi Masa Kini maupun Generasi Masa Depan.

Otto Soemarwoto menyebutkan sumber daya lingkungan mempunyai daya regenerasi dan asimilasi yang terbatas, selama eksploitasi atau permintaan pelayanan ada di bawah batas daya regenerasi atau asimilasi, sumber daya terbaru itu dapat digunakan secara lestari. Akan tetapi apabila batas itu dilampaui, sumber daya itu akan mengalami kerusakan dan fungsi sumber daya itu sebagai faktor produksi dan konsumsi atau sarana pelayanan akan mengalami gangguan. ${ }^{12}$

Jaminan pemanfaatan sumber daya alam akan memberikan manfaat yang sebesar-besarnya bagi kesejahteraan dan mutu hidup rakyat, baik generasi masa kini maupun generasi masa depan sesuai dengan model pembangunan yang diharapkan untuk dilaksanakan yaitu pembangunan yang berkelanjutan. Pembangunan merupakan upaya sadar yang dilakukan oleh manusia untuk mencapai kehidupan yang lebih baik.

Hakikat pembangunan adalah bagaimana agar kehidupan hari ke depan lebih baik dari hari ini. Namun demikian tidak dapat dipungkiri bahwa pembangunan akan selalu bersentuhan dengan lingkungan. ${ }^{13}$

\footnotetext{
${ }^{11}$ Ibid., hlm. 124.

${ }^{12}$ Otto Soemawoto, Ekologi Lingkungan dan Pembangunan, Djambatan, Jakarta, 1994, hlm. 59.

${ }^{13}$ Supriadi, Hukum Lingkungan di Indonesia, Sinar Grafika, Jakarta, 2008, hlm. 38.
} 
Pembangunan dapat menimbulkan resiko-resiko kerusakan pada kemampuan dan fungsi sumber alam dan lingkungan hidup. Resiko-resiko tersebut dapat berupa: ${ }^{14}$ a. rusaknya berbagai sistem pendukung perikehidupan yang vital bagi manusia, baik sistem biofisik maupun sosial; b. munculnya bahaya-bahaya baru akibat ciptaan manusia seperti bahan berbahaya dan beracun dan hasil-hasil bioteknologi; c. pengalihan beban resiko kepada generasi berikutnya atau kepada sektor atau kepada daerah lainnya; dan d. Kurang berfungsinya sistem organisasi sosial dalam masyarakat.

Resiko-resiko ini terutama merupakan hasil interaksi dari tiga faktor utama yaitu: 1. pertambahan penduduk; 2. pertambahan produksi untuk memenuhi kebutuhan penduduk; 3. lembaga-lembaga masyarakat termasuk teknologi yang dikembangkan untuk meningkatkan produksi.

Undang-Undang Nomor 32 Tahun 2009 menggariskan bahwa pola pembangunan Indonesia adalah pembangunan berkelanjutan, yaitu upaya sadar dan terencana yang memadukan aspek lingkungan hidup, sosial, dan ekonomi ke dalam strategi pembangunan untuk menjamin keutuhan lingkungan hidup serta keselamatan, kemampuan, kesejahteraan, dan mutu hidup generasi masa kini dan generasi masa depan.

Pembangunan yang berkelanjutan mempunyai ciri-ciri sebagai berikut: 1 . memberikan kemungkinan kepada kelangsungan hidup dengan jalan melestarikan fungsi dan kemampuan ekosistem yang mendukungny, baik secara langsung maupun tidak lansgung; 2. memanfaatkan sumber alam sebanyak alam atau teknologi pengelolaan mampu menghasilkannya secara lestari; 3. memberikan kesempatan kepada sector dan kegiatan lainnya untuk berkembang secara bersama-sama baik di daerah dan kurun waktu yang sama maupun di daerah dan kurun waktu yang berbeda secara sambung menyambung; 4. meningkatkan dan melestarikan kemampuan dan fungsi ekosistem untuk memasok sumber alam dan melindungi serta mendukung perikehidupan secara terus menerus; 5 . menggunakan prosedur dan tata cara yang memperhatikan kelestarian fungsi dan kemampuan ekosistem untuk mendukung perikehidupan baik masa kini maupun masa yang akan datang.

Untuk menjamin terlaksananya pembangunan berkelanjutan, pemerintah daerah harus memfasilitasi terciptanya good environmental governance, yang bercirikan 7 golden

${ }^{14}$ Harun M Husein, Lingkungan Hidup: Masalah, Pengelolaan dan Penegakan Hukumnya, Bumi Aksara, Jakarta, 1995, hlm. 108-109. 
rules sebagai berikut: ${ }^{15} 1$. pemerintah daerah harus secara proaktif menerjemahkan dan melaksanakan peraturan perundang-undangan lingkungan, baik yang dikeluarkan oleh pemerintah pusat maupun oleh pemerintah provinsi melalui pembuatan dan pelaksanaan peaturan daerah; 2 . dalam melaksanakan pembangunan demi mencapai target PAD, pemerintah daerah harus menyadari tentang keterbatasan daya dukung ekosistem dan keberlanjutan; 3. pemerintah harus menjamin pemberdayaan masyarakat, baik dalam peraturan daerah maupun dalam pengambilan keputusan yang berkaitan dengan pengelolaan lingkungan dan sumber daya alam dalam rangka menjamin terlaksananya pembangunan berkelanjutan. Untuk keperluan ini, pemerintah harus menjamin partisipasi masyarakat dan akses terhadap informasi; 4. pemberdayaan masyarakat dapat dilaksanakan melalui transparansi dalam pembuatan keputusan tentang pengelolaan lingkungan hidup; 5. pemerintah daerah harus menjamin hak masyarakat adat dan setempat dalam tindakannya untuk melakukan pengelolaan sumber daya alam; 6. pemerintah daerah harus menjamin dan mengkoordinasikan harmonisasi kepentingan antara satu sector dengan sector yang lainnya; 7. pemerintah daerah harus secara proaktif menegakkan hukum dan peraturan daerah yang berkaitan dengan pengelolaan lingkungan.

Setiap penyusunan peraturan perundang undangan pada tingkat nasional dan daerah wajib memperhatikan perlindungan fungsi lingkungan hidup dan prinsip perlindungan dan pengelolaan lingkungan hidup sesuai dengan ketentuan yang diatur dalam Undang-Undang Nomor 32 Tahun 2009.

Negara Menjamin Hak Warganegara atas Lingkungan Hidup yang Baik dan Sehat.

Mantan Menteri Lingkungan Hidup Juwono Sudarsono pernah mengatakan bahwa masalah lingkungan hidup tidak dapat dipisahkan dari demokrasi dan hak asasi, karena masalah itu muncul akibat adanya sikap mengabaikan hak-hak rakyat, kurang terbukanya informasi serta lemahnya penegakan hukum. ${ }^{16}$

Siti Sundari Rangkuti mengatakan bahwa hak atas lingkungan hidup yang baik dan sehat dilihat dari sudut bentuk dan isinya, formulasi hak ini bersifat hak asasi klasik, yaitu menghendaki penguasa menghindarkan diri dari campur tangan terhadap kebebasan individu utuk menikmati lingkungan hidupnya. Ditinjau dari bekerjanya, hak itu mengandung tuntutan yang bersifat hak sosial, karena sekaligus

\footnotetext{
${ }^{15}$ Sukanda Husin, Penegakan Hukum Lingkungan Indonesia, Sinar Grafika, Jakarta, 2009, hlm. 18-19.

${ }^{16}$ Hyronimus Rhiti, Kompeksitas Permasalahan Lingkungan Hidup, Universitas Atma Jaya, Yogyakarta, 2005, hlm.
} 39. 
diimbangi dengan keharusan bagi pemerintah untuk menggariskan kebijaksanaan dan melakukan tindakan yang mendorong ditingkatkannya upaya pelestarian lingkungan hidup. ${ }^{17}$

Hak atas lingkungan merupakan hak subjektif setiap manusia yang harus dipertahankan untuk mendapat perlindungan terhadap adanya gangguan dari luar. Heinhard Steiger menyatakan bahwa apa yang dinamakan hak-hak subjektif adalah bentuk yang paling luas dari perlindungan seseorang. Hak tersebut memberikan kepada yang mempunyainya suatu tuntutan yang sah guna meminta kepentingannya akan suatu lingkungan hidup yang baik dan sehat itu dihormati, suatu tuntutan yang dapat didukung oleh prosedur hukum, dengan perlindungan hukum oleh pengadilan dan perangkat-perangkat lainnya. ${ }^{18}$

Heinhard Steiger menyatakan bahwa tuntutan itu mempunyai dua fungsi yang berbeda, yaitu: Fungsi pertama yang dikaitkan pada hak membela diri terhadap gangguan dari laur yang menyebabkan kerugian pada lingkungannya. Fungsi kedua dikaitkan dengan hak untuk dilakukannya sesuatu tindakan agar lingkungannya dapat dilestarikan, dipulihkan atau diperbaiki. ${ }^{19}$

\section{Negara Mencegah Dilakukannya Kegiatan Pemanfaatan Sumber Daya Alam yang Menimbulkan Pencemaran dan/atau Kerusakan Lingkungan Hidup.}

Kegiatan-kegiatan pembangunan dapat mempengaruhi struktur dasar ekosistem melalui dua cara: yaitu eskploitasi sumber alam yang merusak keseimbangan antara komponen-komponen ekosistem, selanjutnya kegiatan pembangunan memberikan muatan beban bahana pencemar yang menimbulkan bahan kerusakan bagi berfungsinya proses-proses alami dalam ekosistem. Kerusakan dasar ekosistem seperti itu merupakan gangguan terhadap kelangsungan hidup manusia, yang sesungguhnya merupakan tujuan pokok dari setiap pembangunan.

Dalam pembangunan dewasa ini, pemerintah dihadapkan kepada dua tugas berat, yang kedua-duanya memerlukan penanganan yang arif dan bijaksana. Kedua tugas berat itu adalah penegakan dan pelaksanaan pembangunan. Kedua tugas berat itu, haruslah diletakkan pada titik keseimbangan dan keserasian yang saling menunjang. Sepintas lalu, kadang kala kedua tugas itu dalam penanganannya

\footnotetext{
${ }^{17}$ Siti Sundari Rangkuti, Hukum Lingkungan dan Kebijaksanaan Nasional, Airlangga University Press, Surabaya, 2000, hlm. 171.

${ }^{18}$ Koesnadi Hardjasoemantri, Hukum Tata Lingkungan, Gadjah Mada University Press, Yogyakarta, 2005, hlm. 102.

${ }^{19}$ Ibid., hlm. 102.
} 
nampak seperti kontradiktif. Penegakan hukum yang semata-mata mengacu kepada kepentingan hukum, tanpa mempertimbangkan kepentingan pembangunan, dapat menimbulkan suatu kondisi yang justru akan menghambat pelaksanaan pembangunan. Terlebih-lebih lagi jika hukum yang akan ditegakkan itu adalah hukum lingkungan. Karena itu dalam konteks ini penegakan hukum lingkungan harus ditempatkan pada titik keseimbangan dan keserasian antara tegaknya hukum dan terlanjutkannya pembangunan berwawasan lingkungan.

Pemerintahan berdasarkan hukum (rule of law) mengharapkan dari masyarakat dan pejabat pemerintah kesetiaan yang kuat kepada hukum. ${ }^{20}$ Upaya negara mencegah dilakukannya kegiatan pemanfaatan sumber daya alam yang menimbulkan pencemaran dan/atau kerusakan lingkungan hidup akan terlaksana apabila terdapat kesetiaan masyarakat dan pemerintah terhadap hukum agar aturan hukum tersebut berdaya guna.

Sebagai hukum fungsional, Undang-undang Pengelolaan Lingkungan Hidup ${ }^{21}$ yang menyediakan tiga macam penegakan hukum lingkungan, yaitu penegakan hukum administrasi, perdata dan pidana. ${ }^{22}$ Andi Hamzah menyebutkan penegakan hukum adalah pengawasan dan penerapan (atau dengan ancaman) penggunaan instrumen administratif, kepidanaan, atau keperdataan untuk mencapai penataan ketentuan hukum dan peraturan yag berlaku umum dan individu. ${ }^{23}$

Di antara ketiga bentuk penegakan hukum yang tersedia, penegakan hukum administrasi dianggap sebagai upaya penegakan hukum terpenting. Hal ini karena penegakan hukum administrasi lebih ditujukan kepada upaya mencegah terjadinya pencemaran dan perusakan lingkungan. Di samping itu, penegakan hukum administrasi juga bertujuan untuk menghukum pelaku pencemaran dan perusakan lingkungan. ${ }^{24}$

Upaya preventif dalam rangka pengendalian dampak lingkungan hidup perlu dilaksanakan dengan mendayagunakan secara maksimal instrumen pengawasan dan perizinan. Dalam hal pencemaran dan kerusakan lingkungan hidup sudah terjadi, perlu dilakukan upaya represif berupa penegakan hukum yang efektif,

\footnotetext{
20 Philippe Nonet, Hukum Responsif, Penerbit Nusa Media, Bandung, 2008, hlm. 77.

${ }^{21}$ Undang-Undang Pengelolaan Lingkungan Hidup Nomor 23 Tahun 1997 telah diganti dengan UndangUndang Nomor 32 Tahun 2009 tentang Perlidungan dan Pengelolaan Lingkungan Hidup.

${ }^{22}$ Takdir Rahmadi, Hukum Pengelolaan Bahan Berbahaya dan Beracun, Airlangga University Press, Surabaya, 2003, hlm. 131.

${ }^{23}$ Andi Hamzah, Penegakan Hukum Lingkungan, Arikha Media Cipta, Jakarta, 1995, hlm. 61.

${ }^{24}$ Sukanda Husin, Op. Cit., hlm. 92.
} 
konsekuen, dan konsisten terhadap pencemaran dan kerusakan lingkungan hidup yang sudah terjadi.

Sehubungan dengan hal tersebut, perlu dikembangkan satu sistem hukum perlindungan dan pengelolaan lingkungan hidup yang jelas, tegas, dan menyeluruh guna menjamin kepastian hukum sebagai landasan bagi perlindungan dan pengelolaan sumber daya alam serta kegiatan pembangunan lain.

Penyelesaian masalah lingkungan melalui instrumen hukum administratif bertujuan agar perbuatan atau pengabaian yang melanggar hukum atau tidak memenuhi persyaratan, berhenti atau mengembalikan kepada keadaan semula sebelum ada pelanggaran. Karena itu, fokus sanksi adaministrasi adalah perbuatannya, sedangkan sanksi dari hukum pidana adalah orangnya. Selain itu, sanksi hukum pidana tidak hanya ditujukan kepada pembuat, tetapi juga kepada mereka yang potensial menjadi pembuat atau pelanggar.

Penegakan hukum perdata merupakan upaya penegakan hukum terpenting kedua setelah hukum administrasi karena tujuan dari penegakannya hanya terfokus pada upaya permintaan ganti rugi oleh korban kepada pencemar atau perusak lingkungan. Namun upaya penegakan hukum perdata merupakan upaya hukum yang meringankan tugas negara, artinya negara tidak perlu mengeluarkan biaya penegakan hukum karena penegakan hukum di sini dilakukan oleh rakyat dan otomatis biayanya ditanggung oleh rakyat. ${ }^{25}$ Penegakan hukum pidana dipandang sebagai ultimum remidium atau upaya hukum terakhir karena penegakan hukum disini ditujukan untuk menjatuhkan pidana penjara atau denda kepada pelaku pencemaran dan/atau perusak lingkungan hidup. ${ }^{26}$

Penegakan hukum pidana dalam Undang-Undang Nomor 32 Tahun 2009 memperkenalkan ancaman hukuman minimum di samping maksimum, perluasan alat bukti, pemidanaan bagi pelanggaran baku mutu, keterpaduan penegakan hukum pidana, dan pengaturan tindak pidana korporasi. Penegakan hukum pidana lingkungan tetap memperhatikan asas ultimum remedium yang mewajibkan penerapan penegakan hukum pidana sebagai upaya terakhir setelah penerapan penegakan hukum administrasi dianggap tidak berhasil. Penerapan asas ultimum remedium ini hanya berlaku bagi tindak pidana formil tertentu, yaitu pemidanaan terhadap pelanggaran baku mutu air limbah, emisi, dan gangguan.

\footnotetext{
${ }^{25}$ Sukanda Husin, Op. Cit., hlm. 92.

${ }^{26}$ Hermien Hadiati Koeswadji, Hukum Pidana Lingkungan, Citra Aditya Bakti, Bandung, 1993, hlm. 126.
} 
Perbedaan mendasar antara Undang-Undang Nomor 23 Tahun 1997 tentang Pengelolaan Lingkungan Hidup dengan undang- undang ini adalah adanya penguatan yang terdapat dalam Undang-Undang ini tentang prinsip-prinsip perlindungan dan pengelolaan lingkungan hidup yang didasarkan pada tata kelola pemerintahan yang baik karena dalam setiap proses perumusan dan penerapan instrumen pencegahan pencemaran dan/atau kerusakan lingkungan hidup serta penanggulangan dan penegakan hukum mewajibkan pengintegrasian aspek transparansi, partisipasi, akuntabilitas, dan keadilan

Proses penegakan hukum lingkungan jauh lebih rumit daripada delik lain, karena hukum lingkungan menempati titik silang pelbagai hukum klasik. Proses penegakan hukum administratif akan lain daripada proses penegakan hukum perdata ataupun hukum pidana. Pada umumnya masalah di mulai dari satu titik, yaitu terjadinya pelanggaran hukum lingkungan. Dari titik berangkat ini dapat dimulai dari orang pribadi anggota masyarakat, korban penegak hukum yang mengetahui langsung terjadinya pelanggaran tanpa adanya laporan atau pengaduan. ${ }^{27}$ Penegakan hukum lingkungan tidak dapat hanya diandalkan pada ketegasan atau kerasnya penegakan hukum tersebut. Penegakan hukum yang dikehendaki ialah penegakan hukum yang tegas, tetapi arif dan bijaksana.

\section{Penutup}

Dari hasil penelitian dapat disimpulkan, pertama, kedudukan asas tanggung jawab negara sebagai dasar pelaksanaan perlindungan dan pengelolaan lingkungan hidup mengandung arti: 1) negara menjamin pemanfaatan sumber daya alam akan memberikan manfaat yang sebesar-besarnya bagi kesejahteraan dan mutu hidup rakyat, baik generasi masa kini maupun generasi masa depan. 2) negara menjamin hak warga negara atas lingkungan hidup yang baik dan sehat. 3) negara mencegah dilakukannya kegiatan pemanfaatan sumber daya alam yang menimbulkan pencemaran dan/atau kerusakan lingkungan hidup.

Kedua, asas tanggung jawab negara sebagai dasar pelaksanaan perlindungan dan pengelolaan lingkungan hidup dilaksanakan melalui penegakan hukum lingkungan, yaitu penegakan hukum administrasi, perdata dan pidana. Di antara ketiga bentuk penegakan hukum yang tersedia, penegakan hukum administrasi

\footnotetext{
${ }^{27}$ Andi Hamzah, Penegakan Hukum Lingkungan, Sinar Grafika, Jakarta, 2005, hlm. 50-51.
} 
dianggap sebagai upaya penegakan hukum terpenting. Hal ini karena penegakan hukum administrasi lebih ditujukan kepada upaya mencegah terjadinya pencemaran dan perusakan lingkungan. Di samping itu, penegakan hukum administrasi juga bertujuan untuk menghukum pelaku pencemaran dan perusakan lingkungan.

\section{Daftar pustaka}

Fatah, Eep Saefulloh, “Betapa Lemahnya Pemerintah”, Kompas, 6 September 2006.

Hakim, Lukmanul, Kedudukan Hukum Komisi Negara di Indonesia; Eksistensi Komisikomisi Negara (State Auxiliary Agency) Sebagai Organ Negara yang Mandiri dalam System Ketatanegaraan, Program Pasca Sarjana Universitas Brawijaya Malang, Puskasi Universitas Widyagama Malang dan Setara Press (Kelompok Penerbit Intrans), Malang, 2010.

Hamzah, Andi, Penegakan Hukum Lingkungan, Arikha Media Cipta, Jakarta, 1995. Penegakan Hukum Lingkungan, Sinar Grafika, Jakarta, 2005.

Hardjasoemantri, Koesnadi, Hukum Tata Lingkungan, Gadjah mada University Press, Yogyakarta, 2005.

Husein, Harun. M, Lingkungan Hidup: Masalah, Pengelolaan dan Penegakan Hukumnya, Bumi Aksara, Jakarta, 1995.

Husin, Sukanda, Penegakan Hukum Lingkungan Indonesia, Sinar Grafika, Jakarta, 2009.

Koeswadji, Hermien Hadiati, Hukum Pidana Lingkungan, Citra Aditya Bakti, Bandung, 1993.

Marzuki, Peter Mahmud, Penelitian Hukum, Kencana Prenada Media Group, Jakarta, 2006.

Nugraha, Safri, "Hukum Administrasi dan Good Governance", Piadato pada Upacara Pengukuhan Guru Besar Tetap pada Universitas Indonesia, 13 September 2006.

Nonet, Philippe, Hukum Responsif, Penerbit Nusa Media, Bandung, 2008.

Rahmadi, Takdir, Hukum Pengelolaan Bahan Berbahaya dan Beracun, Airlangga University Press, Surabaya, 2003.

Rangkuti, Siti Sundari, Hukum Lingkungan dan Kebijaksanaan Nasional, Airlangga University Press, Surabaya, 2000.

Rhiti, Hyronimus, Kompeksitas Permasalahan Lingkungan Hidup, Universitas Atma Jaya Yogyakarta, 2005.

Santosa, Mas Achmad, Good Governance \& Hukum Lingkungan, Indonesian Centre For Environmental Law, Jakarta, 2001.

Siahaan, N.H.T., Hukum Lingkungan, Pancuran Alam, Jakarta, 2009.

Soemawoto, Otto, Ekologi Lingkungan dan Pembangunan, Djambatan, Jakarta, 1994. 
Soerjani, Moh, Lingkungan: Sumber Daya Alam dan Kependudukan dalam Pembangunan, Penerbit Universitas Indonesia, 1987.

Supriadi, Hukum Lingkungan di Indonesia, Sinar Grafika, Jakarta, 2008.

Syarifudin, Ateng, Memantapkan Pemerintahan Yang Bersih Kuat dan Berwibawa, Tarsito, Bandung, 1982.

Undang-undang Dasar 1945

Undang-Undang Nomor 4 Tahun 1982 tentang Ketentuan-ketentuan Pokok Pengelolaan Lingkungan Hidup

Undang-Undang Nomor 23 Tahun 1997 tentang Pengelolaan Lingkungan Hidup

Undang-Undang Nomor 32 Tahun 2009 tentang Perlindungan dan Pengelolaan Lingkungan Hidup. 